\title{
In the Quest of Protecting Financial Investors
}

\author{
Solomon Aborbie \\ Indiana Wesleyan University, USA
}

Tel: 1- 614-589-1778Ｅ-mail: aborbies@gmail.com

Peter Anthony (Corresponding author)

Faculty, Dissertation Chair, Walden University, USA

Tel: 1-253-770-3582_E-mail: peter.anthony@waldenu.edu

Elliot Masocha (Corresponding author)

DeVry University/ Keller Graduate School of Management, USA

Tel: 1-614-312-3191_E-mail: emmasocha@yahoo.com

Received: September 24, 2019 Accepted: October 31, 2019 Published: November 3, 2019

doi:10.5296/ber.v9i4.15507

URL: https://doi.org/10.5296/ber.v9i4.15507

\begin{abstract}
Financial investors remain exposed to investment, financial, and accounting fraud as well as loss of profitability, despite the dictates of the SOX Act of 2002. The most challenging aspect of corporate management is the unexpected nature of an emerging, existing, or an inherent investment or financial risk. Guided by the evolution of fraud theory, this exploratory case study's purpose was to identify and explore the financial management strategies that corporate financial managers need to adequately protect investors. Twenty participants from a population group of corporate auditors of Fortune 1000 corporations provided input for this study. Data from the interviews were analyzed through coding, reviewing, categorizing, and combining common statements. The research findings included themes of knowledge and types of risks; the impact of financial fraud and risks on investment; the impact of accounting, auditing, and financial reporting standards; as well as financial management training to minimize audit expectations. These themes formed the focus of exploring the financial management strategies that corporate financial managers need to adequately protect investors and investments.
\end{abstract}

Keywords: Affinity fraud, Financial fraud, Fraudulent channels, Neurofinance 


\section{Introduction}

This study to decrease financial fraud in corporations is also aimed at protecting investment and investors, we considered the perpetuation of financial fraud and focused on effective ways of creating awareness, minimizing leakages, increasing profitability, and restoring investors' confidence in the management of corporations. According to Dorminey, Fleming, Kranacher, and Riley (2012), financial fraud and other types of corporate crime have existed since the origins of commerce. Although the study was further grounded by the formation of the Financial Fraud Enforcement Task Force (FFETF) by President Obama of the United States in November of 2009, the challenge still looms (Apostolou \& Apostolou, 2013).

Intentional miscalculation, falsification of accounting records, deliberate commission of fraud, omissions from financial statements, misinterpretation, and misapplication of generally accepted accounting principles and standards are some of the means by which company revenue and assets can be compromised (Pallisserry, 2012). Some corporate policies that authorize managers to override established internal controls may lead to underdeclaration of revenues (Pallisserry, 2012). Graycar and Sidebottom (2012) estimated the cost of corporate fraudulent activities as $\$ 2.6$ trillion per annum, comprising up to 5\% of the gross domestic product. Crawford and Weirich (2011) referred to fraudulent financial accounting practices as a deception to investors and other stakeholders. In addition, Button, Gee, and Brooks (2012) measured the average percentage loss rate and the fraud frequency rate as $5.4 \%$ and $9 \%$, respectively, within large organizations. This trend of business projects a gloomy picture for investors and corporate management.

\section{Purpose}

The purpose of this exploratory, qualitative case study was to identify and explore the financial management strategies that corporate financial managers need to adequately protect investors. Even though investors blame auditing firms for financial fraud, there is the need to explore corporate financial management activities as the basis for fraud. According to Kassem and Higson (2012), increases in fraudulent financial reporting and perpetuation of fraud in corporations have become major concern for investors. Kassem and Higson reported the need for academic researchers and management to complement the effort of policy regulators to narrow the gap of financial fraud.

This study is important to the body of research because fraud can have a substantially negative impact on a business, no matter the size or type. Whether fraud occurs by means of misappropriation of assets by employees or fraudulent financial reporting by management, the perpetuation of fraud leads to financial loss, public mistrust, loss in market share, negative corporate cultural and morale effect, as well as increase in investigative and audit costs.

The population group for this study was corporate auditors, certified public accountants (CPAs), and corporate fraud examiners (CFEs), of Fortune 1000 corporations because of the impact of their audit on corporate financial managers. The study's sample included 20 interview participants in addition to archived data. These 20 individuals provided data 


\section{Macrothink}

saturation. We selected these participants for their accessibility, experiences, and perceptions about financial regulations and standards (Desmarais \& Read, 2011). The findings from the study might contribute to social change by determining efficient methods for corporate managers to detect and minimize financial fraud, increase profitability, ensure employment security, and provide continuous service to communities.

\section{Literature Review}

The evolution of fraud theory emerged in 2011 following guidance by the Public Company Accounting Oversight Board (PCAOB) to enable auditors and responsible management to deter, detect, correct, and fairly manage fraudulent practices in corporations. Dorminey et al. (2012) based their meta-model concept on the foundations of the fraud triangle which originated in the early 1950s in the United States.

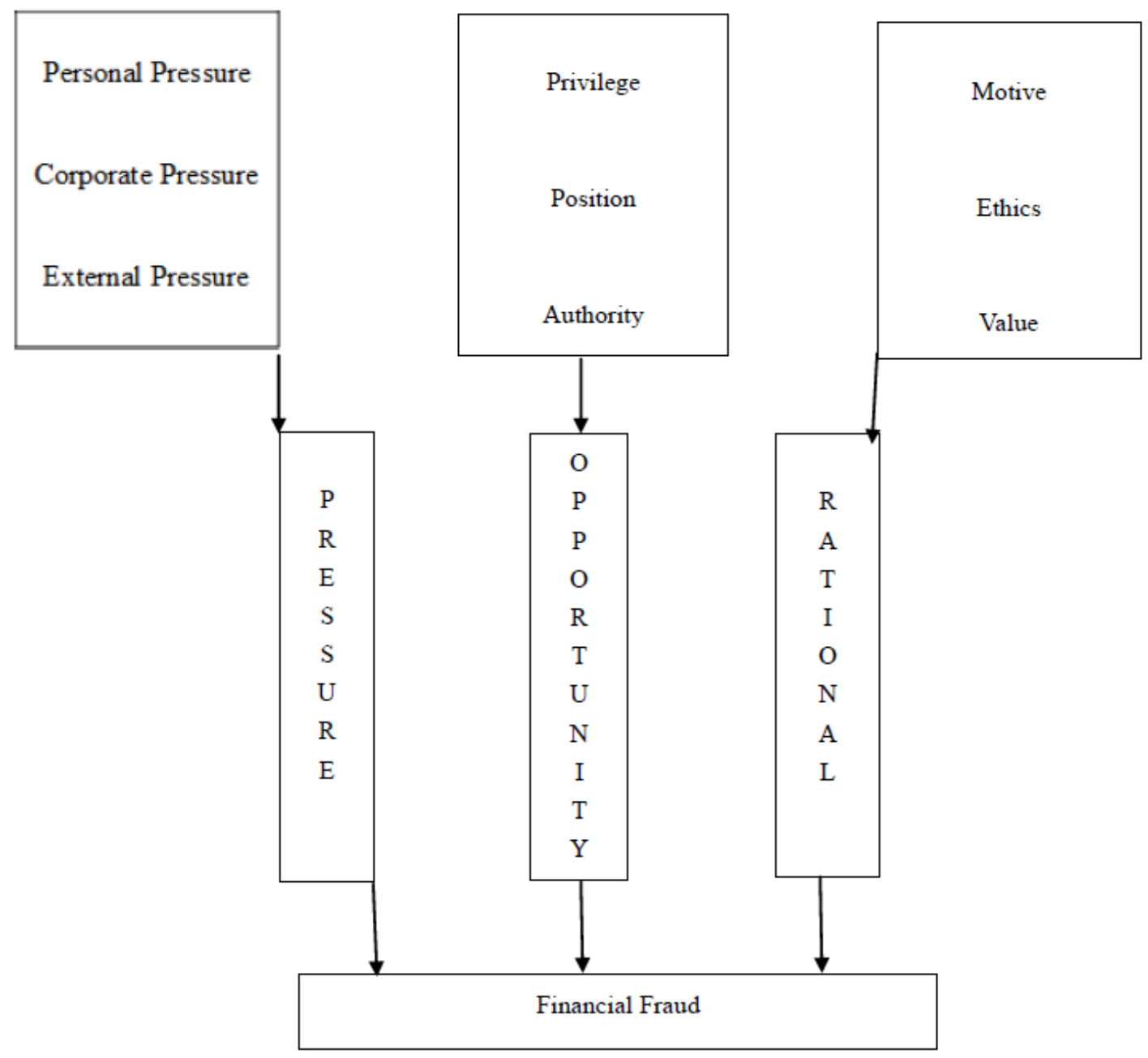

Figure 1. Diagram of elements of fraud

The elements of pressure, opportunity, and the rational to commit financial fraud in corporations. Adapted from "The New Fraud Triangle Model," by R. Kassem and A. Higson, 2012, Journal of Emerging Trends in Economics and Management Sciences, 3, p. 192. Copyright 2012 by the Scholarlink Research Institute Journals. 
The developers of the concept of financial fraud triangle took into consideration its inception and evolution. Kindleberger and Aliber (2011) wrote that financial fraud began at the inception of trade and before what was recorded in the History of the National Loans of the U. S. from July 4, 1776 to June 30, 1880. Financial fraud also began before the History Sketches of the Paper Currency of the American Colonies prior to the adoption of the federal Constitution (Kindleberger \& Aliber, 2011). The authors traced the activities of barter traders through the first financial fraud report in 1600 at the British East India Company to contemporary cases of Enron and Tyco. Dorminey et al. (2011) developed the concept of financial fraud and linked to the A-B-C analysis of white-collar fraud as well. Kranacher et al. (2011), however, noted the inconsistent relationship between financial fraud and income levels.

In this section of the review, we considered researchers' studies on corporate fraud. Katsis et al. (2012) wrote that financial fraud is the manipulation of financial figures by highly trusted and responsible managers, as well as employees, to present their corporations favorably to investors, financial analysts, and other users of financial statements. Financial fraud is therefore aimed at projecting a corporation as more successful than finances actually show. In line with the definition of financial fraud, Abels and Martelli (2012), Cohen et al. (2010), and Frankel (2012) chided CEOs for the knack of making unethical financial decisions.

Financial fraud by corporate management still needs exploration and rectification. Cohen et al. (2010) and Ruankaew (2013), who outlined the existing literature of financial fraud in areas of business, criminology, psychology, sociology, ethics, and moral development, wanted to know management's key role to minimize the rising trend of financial fraud. These quantitative researchers revealed their inability to obtain considerable evidence by manipulation of the three variables of attitudes, opportunities, and incentives. Cohen et al. (2010) and Ruankaew (2013) therefore implored future academicians and researchers to explore financial fraud by using a qualitative method. This study is an answer to Cohen et al. and Ruankaew's urgent call for further research.

The call for scrutiny in financial fraud cases must be linked with corrective measures. Ngai, $\mathrm{Hu}$, Wong, Chen, and Sun (2011) argued that there is insufficient research to analyze the detrimental effect of financial fraud. The setting up of unrealistic managerial goals with their attractive incentives has paved way for the perpetuation and justification of financial fraud in corporations (Williams, 2012). McGurrin (2013) contributed to the understanding of financial fraud and crime by suggesting the study of criminology, ethical concepts, social, and criminal justice to uproot fraud. As corruption and fraud emerged at the same time as the commencement of barter trade, formulation of regulations and policies to counteract these behaviors might have also commenced in the same era. However, Teed (2013) observed the failure of the SEC to enforce policies on financial reporting. The inability of the SEC to deter corporate misbehavior emboldens managerial misdeeds (Teed, 2013).

Financial fraud, manipulation of assets and liabilities, and other unethical behavior have increased in all spheres of business transactions and management. Although Teed (2013) attributed the increase in financial fraud by managers and employees to the lack of control by 
the SEC, Frankel (2012) on the other hand blamed the complexity of information technology. When employees and managers lack the necessary training and exposure to use ever-changing information technology and to understand security implications, they commit errors to the detriment of the organization.

Perri and Brody (2013), conversely, attributed the rise in financial fraud and other corrupt business practices to characteristics of affinity. Affinity fraud thrives on the trust and confidence employees and management accord parties outside the corporation. The reliance on affiliations leads to the siphoning of information and valuable resources. Rival corporations capitalize on the acquired information as a competitive edge.

Focusing on management activities is a direct approach in minimizing financial fraud in corporations. On the basis of identifying management as the first line of financial fraud, Demerens, Pare, and Redis (2013) categorized fraud into incorrect recognition of revenue, shifting of contemporary expenses to future periods, poor classification of expenses, overvaluation of assets, and undervaluation of liabilities. Graycar and Sidebottom (2012) broadened the definition of fraud to include favoritism, clientelism, neptotism, discretionary abuse, bribery, extortion, and mishandling of conflict of interest. These unethical behaviors include irresponsibility in personnel appointment, program design and implementation, procurement, contract deals, and abuse of authority and responsibility. Another area of fraud suggested by Dickins and Reisch (2012) deals with accounting information systems, information technology, and risk identification and analysis.

The contention around fraudulent activities and shifting of blame in fraud detection are exacerbating problems in the audit marketplace. Although major auditing firms strategize to avoid risky businesses, Cullinan and Du (2012) reported management open new businesses with second and middle-tier auditing firms. This new trend suggests the readiness of the second and middle-tier auditing firms to take on risky business while major auditing firms maintain protective regulations.

SEC's risk-based examination processes; and Abeysekera (2012) suggested the use of a uniform and integrated reporting template. The proposed templates, models, and processes focus on helping corporations attain their objectives with limited resources and aiding management to effectively combine financial and intellectual capital for innovative leverage. Researchers have assessed the nondeterrent nature of sanctions of (McDonald, 2013), of unrealistic managerial goals (Williams, 2012), and of the creation of neurofinance (Sahi, 2012). However, only few studies have examined the quest for investment and investor protection.

\section{Methodology}

Research methods consist of the forms of data collection, coding, analysis, and interpretation researchers use for their studies. The three different methods applied in research are the qualitative, quantitative, and mixed methods (Frels \& Onwuegbuzie, 2013; Zohrabi, 2013). The research method we used in this study of minimizing financial fraud in corporations and the quest to protect investors was qualitative because the collection of data involved 
emerging questions and procedures. The qualitative method was applicable for the research because such an approach is appropriate for developing an understanding on a specific phenomenon, group, or situation, and formulating conclusions about observations, according to Bernard (2013). A qualitative study methodology is about analysis of events and the collection of rich data (Cilesiz, 2011; Gilligan \& Kypri, 2012). A qualitative approach explores the effects of a study without leading or distorting narratives of participants (Hafstad, Haavind, \& Jensen, 2012). Due to the major elements of social context, a qualitative approach for this research enabled us to consider objective information in arriving at sustainable conclusions, as indicated by Kisely and Kendall (2011).

The justification for using the qualitative method also include the fact that the method enhances (a) subject materials that can be evaluated with greater detail, (b) creative and desirable quality within qualitative research, (c) structures that are fluid and based on incoming or available data, (d) attitude explanations, and (d) incorporation of complexities of data into generated conclusions where necessary.

Carenza (2011) explained research design as an action plan that connects theoretical frameworks, the research question, and the research method. We used the case study design to explore the practical experiences of auditing professionals as a means of mitigating financial fraud in corporations. The focus of this qualitative case study was to explore the auditors' perceptions and experiences for an in-depth exploration of the central phenomenon (Gilligan \& Kypri, 2012). The methodological framework for this qualitative case study provided a theoretically informed means to study how to minimize financial fraud in corporations. The qualitative method allowed for semistructured, open-ended questions, and participants' effective input. Miers, Abbott, and Springer (2012) concluded that open-ended questions and semistructured interviews were efficient methods for exploration. Likewise, Kisely and Kendall (2011) supported the application of open-ended questions to ease exploration of the phenomenon under study by using the qualitative approach. The prime methods for gathering data were semistructured interviews and analysis of archived documents.

\section{Results}

With the conceptual framework underlying the study of the financial management strategies corporate financial managers need to adequately protect investors, Dorminey et al. (2011) discussed the concept concerning the rationale of pressure and opportunity. Participants agreed that identifying financial fraud perpetuated by insiders is as equally difficult as managing it. We also learned from participants that although fraudsters threaten corporations by the debilitating nature of financial fraud and other emerging risks, the distinguishing feature among corporations which lose and those which manage the threat depends on a well-prepared management team. Management's readiness to (a) anticipate, (b) prevent, (c) detect, (d) control, (e) correct, (f) manage, and (g) monitor the effect of risks at all levels determines the mark of success and the degree of confidence upheld by the investing public. Some participants suggested the institutionalization of a strong task force with the monitoring control over dubious and unscrupulous activities from investigation. Participants also suggested intelligence activities, vigilante, whistleblower, and hotline discoveries. Blount and 
Markel (2012) however argued the whistleblower provision was described by critiques as intrusive and unnecessary.

An area of emerging concern is the threat of information and identity theft of corporations and their clients. Faceless fraudsters continue to test the vulnerability of company cyber defenses by the acceleration of constant and consistent probing with sophisticated e-tools (McDonald, 2013). In the recognition and evaluation of threats, corporate management must welcome different inclusive policies. Addressing the problem of financial fraud requires the cooperation of all stakeholders at all the internal and external levels of the business environment.

The inclusive approach consists of the interaction and cooperation from the smallest unit to the highest concerns of the Foreign Corrupt Practices Act (FCPA) of the United States, the Bribery Act of Britain or United Kingdom, and Transparency International (TI). The TI usually provides an index on fraud for stopping corruption and promoting transparency, accountability and integrity at all levels and across all sectors of society in the world. Corporate managers must also fill the fraudulent gap by the provision and extension of resources to sustain investment in global information and technological security. The global technological information and security sustains the strength of the United Nations and other secular and regional integrations or organizations. From the literature review, we have assessed the role of knowledge management systems (Ramanigopal, 2013), of corporate social responsibility (Zhang \& Gowan, 2012), of forensic examination (Okoye \& Gbegi, 2013), of management's professional integrity (Dickins \& Reisch, 2012), and of the role of auditors in corporate governance (Dobroteanu et al., 2011).

\section{Conclusions}

The research question that guided this study was: What financial management strategies do corporate financial managers need to adequately protect investors? The foundation of the study was based on the formulation of Financial Fraud Enforcement Task Force (FFETF) instituted by the President of the United States in November of 2009 to minimize financial fraud nationwide and to serve as pragmatic lessons for other observing nations. The findings from this study could benefit financial and investment managers constantly confronted with issues of financial risks and fraud in developing financing and investing strategies. The study participants provided exceptional and adequate insights into the difficulties and challenges management encounters in investment decisions and analysis. Organizational leaders must be aware of the consequences of amassing wealth through fraudulent channels and be willing to adapt to changes from training programs when possible.

Addressing the problem of financial fraud requires the cooperation of all stakeholders at all the internal and external levels of the business environment. The readiness of management teams to anticipate, prevent, detect, control, correct, manage, and attenuate the effect of risks at all levels determines the mark of success as well as the degree of confidence and trust upheld by the investing public. Acquiring and updating the requisite and evolving skills to combat the menacing threat of risks and uncertainties could enable organizational leaders to potentially expand corporate business for employment, enhancement of productivity and 
growth to maximize social responsibilities, profitability, resources, and wealth in the United States of America and beyond.

\section{References}

Abels, P. B., \& Martelli, J. T. (2012). Independence and firm performance. Global Conference on Business and Finance Proceedings, 7, 81-85. [Online] Available:

http://www.theibfr.com/proceedings.htm

Abeysekera, I. (2013). A template for integrated reporting. Journal of Intellectual Capital, 14, 227-245. https://doi.org/10.1108/14691931311323869Homa Mahmoodzadeh

Apostolou, B., \& Apostolou, N. (2013). The value of risk assessment: Evidence from recent surveys. The Forensic Examiner, 21(3), 14-22. [Online] Available:

http://www.theforensicexaminer.com

Bernard, H. R. (2013). Social research methods: Qualitative and quantitative approaches (2nd ed.). Thousand Oaks, CA: Sage Publications, Inc.

Blount, J., \& Markel, S. (2012). The end of internal compliance world as we know it or, an enhancement of the effectiveness of securities law enforcement? Bounty hunting under the Dodd-Frank Act's whistleblower provisions. Fordham Journal of Corporate \& Financial Law, 17, 1023-1062. https://doi.org/10.2139/ssrn.1925463

Button, M., Gee, J., \& Brooks, G. (2012). Measuring the cost of fraud: An opportunity for the new competitive advantage. Journal of Financial Crime, 19, 65-75.

https://doi.org/10.1108/13590791211190731

Carenza, G. S. (2011). A phenomenological study of mindfulness of curriculum directors in a Midwest state (Doctoral dissertation). Retrieved from ProQuest Dissertations \& Theses database. (UMI No. 3474865)

Cilesiz, S. (2011). A phenomenological approach to experiences with technology: Current state, promise, and future directions for research. Educational Technology Research and Development, 59, 487-510. https://doi.org/10.1007/s11423-010-9173-2

Cohen, J., Ding, Y., Lesage, C., \& Stolowy, H. (2010). Corporate fraud and managers' behavior: Evidence from the press. Journal of Business Ethics, 95, 271-315.

https://doi.org/10.1007/s10551-011-0857-2

Crawford, R. L., \& Weirich, T. R. (2011). Fraud guidance for corporate counsel reviewing financial statements and reports. Journal of Financial Crime, 18, 347-360.

https://doi.org/10.1108/13590791111173696

Cullinan, C. P., \& Du, H. (2012). Client selectivity among mid-sized auditing firms: Evidence from the post-sox audit market realignment. Journal of Business \& Economics Research, 10, 601-612. https://doi.org/10.19030/jber.v10i11.7359

Demerens, F., Pare, J., \& Redis, J. (2013). Investor skepticism and creative accounting: The case of a French SME listed on alters next. International Journal of Business, 18(1), 59-81. 
[Online] Available: http://www.craig.csufresno.edu/ijb

Desmarais, S., \& Read, D. J. J. (2011). After 30 years, what do we know about what jurors know? A meta-analytic review of lay knowledge regarding eyewitness factors. Law \& Human Behavior, 35, 200-210. https://doi.org/10.1007/s10979-010-9232-6

Dickins, D., \& Reisch, J. T. (2012). Enhancing auditors' ability to identify opportunities to commit fraud: Instructional resource cases. Issues in Accounting Education, 27, 1153-1169. https://doi.org/10.2308/iace-50178

Dobroteanu, L., Coman, N., \& Dobroteanu, C. L. (2011). External auditors and corporate governance under the impact of financial crisis. Audit Financiar, 9, 13-26. [Online] Available: http://www.revista.cafr.ro

Dorminey, J., Fleming, A. S., Kranacher, M., \& Riley, Jr., R. A. (2012). The evolution of fraud theory. American Accounting Association, 27, 555-579.

https://doi.org/10.2308/iace-50131

Frankel, T. (2012). The Ponzi scheme puzzle: A history and analysis of con artists and victims. New York, NY: Oxford University Press.

https://doi.org/10.1093/acprof:osobl/9780199926619.001.0001

Frels, R. K., \& Onwuegbuzie, A. J. (2013). Administering quantitative instruments with qualitative interviews: A mixed research approach. Journal of Counseling and Development, 91, 184-194. https://doi.org/10.1002/j.1556-6676.2013.00085.x

Gilligan, C., \& Kypri, K. (2012). Parent attitudes, family dynamics and adolescent drinking: Qualitative study of the Australian parenting guidelines for adolescent alcohol use. BMC Public Health, 12, 491-501. https://doi.org/10.1186/1471-2458-12-491

Graycar, A., \& Sidebottom A. (2012). Corruption and control: A corruption reduction approach. Journal of Financial Crime, 19, 384-399.

https://doi.org/10.1108/13590791211266377

Hafstad, G., Haavind, H., \& Jensen, T. (2012). Parenting after a natural disaster: A qualitative study of Norwegian families surviving the 2004 tsunami in Southeast Asia. Journal of Child \& Family Studies, 21, 293-302. https://doi.org/10.1007/s10826-011-9474-Z

Kassem, R., \& Higson, A. (2012). Financial reporting fraud: Are standards' setters and external auditors doing enough? International Journal of Business and Social Science, 3(19), 283-290. [Online] Available: http://www.ijbssnet.com

Katsis, C. D., Goletsis, Y., Boufounou, P. V., Stylios, G., \& Koumanakos, E. (2012). Using ants to detect fraudulent financial statements. Journal of Applied Finance and Banking, 2(6), 73-81. [Online] Available: http://www.scienpress.com/journal_focus.asp?Main_Id=56

Kindleberger, C. P., \& Aliber, R. C. (2011). A maniac, panic, and crashes: A history of financial crises. New York, NY: St Martin's Press.

Kisely, S., \& Kendall, E. (2011). Critically appraising qualitative research: A guide for 
clinicians more familiar with quantitative techniques. Australasian Psychiatry, 19, 364-367. https://doi.org/10.3109/10398562.2011.562508

MacDonald, R. (2013). Setting examples, not settling: Toward a new SEC enforcement paradigm. Texas Law Review, 91, 419-447. [Online] Available:

http://www.utexas.edu/law/journals/tlr/

McGurrin, D. (2013). The theft of a nation symposium: Introduction. Western Criminology Review, 14(2), 20-22. [Online] Available: http://wcr.sonoma.edu/

Miers, D., Abbott, D., \& Springer, P. R. (2012). A phenomenological study of family needs following the suicide of a teenager. Death Studies, 36, 118-133.

https://doi.org/10.1080/07481187.2011.553341

Ngai, E. W. T., Hu, Y., Wong, Y. H., Chen, Y., \& Sun, X. (2011). The application of data mining techniques in financial fraud detection: A classification framework and an academic review of literature. Decision Support Systems, 50, 559-569.

https://doi.org/10.1016/j.dss.2010.08.006

Okoye, E. I., \& Gbegi, D. O. (2013). Forensic accounting: A tool for fraud detection and prevention in the public sector. International Journal of Academic Research in Business and Social Sciences, 3(3), 1-19. [Online] Available: http://www.hrmars.com/journals

Pallisserry, F. (2012). True and fair financial reporting: A tool for better corporate governance. Journal of Financial Crime, 19, 332-342. https://doi.org/10.1108/13590791211266331

Perri, F. S., \& Brody, R. G. (2012). The optics of fraud: Affiliations that enhance offender credibility. Journal of Financial Crime, 19, 355-370.

https://doi.org/10.1108/13590791211266359

Ramanigopal, C. (2013). Systematic route map to knowledge management. International Journal of Management Research and Review, 3, 2149-2155. [Online] Available: http://www.ijmrr.com

Ruankaew, T. (2013). The fraud factors. International Journal of Management and Administrative Sciences, 2(2), 1-5. [Online] Available: http://www.ijmas.org/

Sahi, S. K. (2012). Neurofinance and investment behavior. Studies in Economics and Finance, 29, 246-267. https://doi.org/10.1108/10867371211266900

Teed G. D. (2013). Legislation of ethics in the early years of the Securities and Exchange Commission. Review of Business and Finance Studies, 4(2), 1-10. [Online] Available:

http://www.theibfr.com/rbfcs.htm

Williams, G. W. E. (2012). Policy implications of different theoretical approaches to organized crime. Journal of Financial Crime, 19, 400-409.

https://doi.org/10.1108/13590791211266386

Zhang, W., \& Wu, Z. (2012). A study on establishing low-carbon auditing system in China. Low Carbon Economy, 3, 35-38. https://doi.org/10.4236/lce.2012.32005 


\section{Copyright Disclaimer}

Copyright for this article is retained by the author(s), with first publication rights granted to the journal.

This is an open-access article distributed under the terms and conditions of the Creative Commons Attribution license (http://creativecommons.org/licenses/by/3.0/). 